\title{
Pemilihan Lampu Pada Sistem Pencahayaan Perpustakaan Menggunakan Metode Fuzzy AHP
}

\author{
Frisheila Sely Apriliana ${ }^{1}$, Bambang Suhardi*2 \\ 1,2Program Studi Teknik Industri, Universitas Sebelas Maret, Jalan Ir Sutami 36A, \\ Kentingan, Jebres, Surakarta, 57126 \\ e-mail: ${ }^{1}$ freesela@gmail.com, *2 bambangsuhardi@ staf.uns.ac.id
}

\section{(artikel diterima: 03-06-2020, artikel disetujui: 29-06-2021)}

\begin{abstract}
Abstrak
Aspek pencahayaan penting untuk diperhatikan demi menciptakan lingkungan perpustakaan yang baik. Pemilihan lampu sebagai sumber cahaya buatan harus disesuaikan dengan kebutuhan perpustakaan. Penelitian ini bertujuan memilih lampu yang sesuai untuk perpustakaan pusat Universitas Sebelas Maret. Metode yang digunakan ialah Fuzzy Analytical Hierarchy Process (Fuzzy AHP). Responden penelitian adalah 1) staf bagian rumah tangga, selaku pihak yang bertanggung jawab secara administrasi mengenai pengadaan barang di perpustakaan, 2) staf pengelola Sistem Informasi Manajemen dan Akuntansi Barang Milik Negara (SIMAK BMN) bagian listrik, sebagai pihak yang bertanggung jawab secara teknis mengenai peralatan listrik yang ada di perpustakaan, dan 3) staf unit layanan pengadaan selaku pihak yang bertanggung jawab terhadap pengadaan barang. Terdapat tiga alternatif merk lampu yang dipertimbangkan dalam penelitian ini yaitu Philips, Hannoch dan OSRAM. Tiga alternatif merk lampu tersebut digunakan karena memiliki produk dengan nilai lumen yang sesuai dengan spesifikasi lumen tiap lampu di perpustakaan. Hasil perankingan fuzzy AHP menunjukkan bahwa urutan prioritas lampu yang terpilih ialah Philips, OSRAM, dan Hannoch dengan bobot masing-masing 43\%, 38\%, dan $18 \%$.
\end{abstract}

Kata kunci: Fuzzy AHP, lampu, pencahayaan, perpustakaan

\begin{abstract}
The lighting aspect is important to create a good library condition. The selection of lamps as artificial light sources must be adjusted to the library needs. This research aims to select the lamps that is suitable to the need of the central library of Sebelas Maret University. The methods used in this research was Fuzzy Analytical Hierarchy Process (Fuzzy AHP). In this study, the respondents were the staf of the Household Section, who is in charge of administration regarding the procurement of goods in the library, the staf of management and accounting information system of state property (SIMAK BMN) of the electricity section who responsible technically about the electrical equipment in the library and the Procurement Services Unit staf who responsible for procurement of goods. There were three alternative lighting brands considered in this study, namely Philips, Hannoch and OSRAM. Three alternative lighting brands were used because they have a lumen value that matches to the lumen specifications of library lamp. The results of fuzzy AHP showed that the order of
\end{abstract}


priority of the lamps chosen were Philips, OSRAM, and Hannoch with weights of 43\%, $38 \%$, and $18 \%$, respectively.

Keywords: Fuzzy AHP, lamp, lighting, library

\section{PENDAHULUAN}

Pencahayaan merupakan aspek penting yang diperlukan dalam menunjang produktivitas manusia. Menurut Hadikurniawati dan Amin (2016), fungsi cahaya adalah untuk menyediakan lingkungan yang aman secara visual, menyediakan lingkungan visual yang nyaman dan aman serta memberikan kemudahan dalam menyelesaikan pekerjaan. Pencahayaan yang buruk dapat mengganggu aktivitas manusia dan dapat menimbulkan gangguan kesehatan penglihatan (Milaningrum, 2015).

Perpustakaan membutuhkan pencahayaan yang memadai untuk menunjang produktivitas pengguna perpustakaan. Aktivitas membaca merupakan kegiatan utama yang dilakukan diperpustakaan, sehingga dalam design perpustakaan pencahayaan merupakan aspek yang harus diperhatikan (Omar et al., 2018). Pemilihan lampu yang digunakan secara tepat diperlukan untuk mengetahui tingkat kebutuhan pencahayaan di perpustakaan.

Metode pemilihan lampu di perpustakaan dapat menggunakan multi atribute decission making (MADM). Secara umum, MADM biasanya diterapkan dalam pengambilan keputusan yang dilakukan oleh beberapa pemangku kepentingan (Bai et al., 2018). Fuzzy Anaytical Hierarchy Process (Fuzzy AHP) merupakan salah satu metode dalam MADM. Fuzzy AHP merupakan suatu metode analisis mengenai pengambilan keputusan majemuk yang dikembangkan dari AHP. Fuzzy AHP mampu mengatasi ambiguitas pendapat manusia mengenai pengambilan keputusan dengan lebih baik dibanding metode AHP tradisional (Mardani et al., 2016). AHP tidak mampu menggabungkan ketidakpastian dan ketidakjelasan pengambil keputusan, oleh karena itu AHP diselesaikan dengan fungsi keanggotaan bilangan fuzzy untuk mengatasi ketidakjelasan dan ketidakpastian tersebut (Nirmala dan Uthra, 2019). Selain itu, pendekatan fuzzy AHP memberikan lebih banyak fleksibilitas untuk menangani variasi penilaian dari pembuat keputusan (Zarghami et al., 2018). Penelitian ini bertujuan untuk menggunakan metode fuzzy AHP dalam pengambilan keputusan mengenai jenis lampu yang digunakan dalam sistem pencahayaan perpustakaan.

\section{METODE PENELITIAN}

Pemilihan alternatif lampu pada sistem pencahayaan di perpustakaan dilakukan menggunakan metode Fuzzy AHP. Metode Fuzzy AHP merupakan pengembangan dari metode AHP yang terdiri dari unsur-unsur matriks yang diwakili oleh bilangan fuzzy (Sonalitha, Sarosa dan Naba, 2015). Meskipun AHP bisa digunakan untuk menangani kriteria kuantitatif dan kualitatif pada MADM namun fuzzy AHP dianggap mampu mendeskripsikan keputusan yang samar dengan lebih baik dibandingkan AHP (Andalia, Iftadi dan Jauhari, 2014). Selain itu, Fuzzy AHP juga mampu menutupi permasalahan subjektifitas pada AHP (Fajri, Putri dan Muflikhah, 2018). Ketidakpastian bilangan pada AHP direpresentasikan dengan urutan skala (Ekastini, Kusrini dan Luthfi, 2018). Tahapan fuzzy AHP adalah: 


\subsection{Matriks Perbandingan Berpasangan (Pairwise Comparison Matrix)}

Semua kriteria dan sub kriteria dibandingkan dengan memberikan bobot pada masing-masing perbandingan dengan berpedoman pada Tabel 1.

Tabel 1 Skala penilaian perbandingan berpasangan

\begin{tabular}{cll}
\hline Tingkat kepentingan & \multicolumn{1}{c}{ Definisi } & \multicolumn{1}{c}{ Keterangan } \\
\hline 1 & $\begin{array}{l}\text { Kedua elemen sama } \\
\text { penting }\end{array}$ & $\begin{array}{l}\text { Kedua elemen mempunyai } \\
\text { kontribusi yang sama } \\
\text { terhadap pilihan }\end{array}$ \\
3 & $\begin{array}{l}\text { Elemen yang satu } \\
\text { sedikit lebih penting } \\
\text { dari yang lain }\end{array}$ & $\begin{array}{l}\text { Elemen yang satu memiliki } \\
\text { kontribusi sedikit lebih } \\
\text { penting dari yang lain }\end{array}$ \\
& $\begin{array}{l}\text { Elemen yang satu } \\
\text { lebih penting dari }\end{array}$ & $\begin{array}{l}\text { Elemen yang satu memiliki } \\
\text { kontribusi lebih penting dari }\end{array}$ \\
& yang lain & yang lain \\
& Elemen yang satu & Elemen yang satu memiliki \\
& sangat lebih penting & kontribusi sangat lebih \\
dari yang lain & penting dari yang lain \\
& Elemen yang satu & Elemen yang satu memiliki \\
& mutlak lebih penting & kontribusi mutlak lebih \\
dari yang lain & penting dari yang lain \\
& Nilai tengah antar dua & Jika terdapat dua keraguan \\
pertimbangan yang & antara dua penilaian yang \\
& berdekatan & berdekatan \\
\hline \multirow{2}{*}{$2,4,6,8$} & &
\end{tabular}

Sumber : Saaty (1994)

\subsection{Agregasi Penilaian Berpasangan}

Penilaian berdasarkan responden akan menghasilkan pendapat yang berbeda. Pada tahap agregasi, Saaty (1994) menggunakan perhitungan rataan geometrik dikarenakan bilangan yang dirata-rata merupakan bilangan yang bersifat rasio dan mampu mengurangi gangguan yang muncul akibat salah satu bilangan terlalu besar atau terlalu kecil (Mardhikawarih, Jauhari dan Rosyidi, 2012). Rataan Geometrik secara matematis dituliskan pada persamaan (1).

$$
\alpha i j=(Z 1, Z 2, Z 3, \ldots Z n) 1 / n
$$

Dimana:

aij = Nilai rata-rata pebandingan berpasangan kriteria $\mathrm{Ai}$ dengan $\mathrm{Aj}$ untuk $\mathrm{n}$ partisipan.

$\mathrm{Zi}=$ Nilai pebandingan antara kriteria Ai dengan Aj untuk partisipan $\mathrm{i}$ dengan $\mathrm{i}=$ $1,2,3, . ., \mathrm{n}$ 


\subsection{Uji Konsistensi}

Menurut Saaty dan Vargas (2012), ketidakkonsistenan mungkin terjadi dalam metode AHP karena menggunakan persepsi pembuat keputusan sebagai inputnya dan manusia memiliki keterbatasan dalam menyatakan persepsinya. Oleh karena itu perlu dilakukan uji konsistensi dilakukan untuk membuktikan apakah matriks perbandingan berpasangan tersebut konsisten. Tahapan uji konsistensi dalam fuzzy AHP adalah sebagai berikut:

Langkah $1:$ menghitung nilai vektor eigen dan $\lambda$ maksimum

Langkah 2 : menghitung nilai CI (Consistency Index) dengan persamaan (2) :

Dimana :

$$
C I=\frac{\lambda \max -n}{n-1}
$$

$\mathrm{CI}=$ Indeks konsistensi (Consistency Index)

$\lambda$ maks $=$ rata-rata nilai eigen value

$\mathrm{n} \quad=$ ordo matriks

Langkah 3 : Menghitung nilai Consistency Ratio (CR) dengan persamaan (3):

$$
C R=\frac{C I}{R I}
$$

Dimana :

$\begin{array}{ll}\mathrm{CR} & =\text { Consistency Ratio } \\ \mathrm{RI} & =\text { Random Index }(\text { Tabel } 2)\end{array}$

Tabel 2 Random Index

\begin{tabular}{cc}
\hline Ukuran Matriks (n) & Random Index (RI) \\
\hline 1 & 0,00 \\
2 & 0,00 \\
3 & 0,58 \\
4 & 0,90 \\
5 & 1,12 \\
6 & 1,24 \\
7 & 1,32 \\
8 & 1,41 \\
9 & 1,45 \\
10 & 1,49 \\
11 & 1,51 \\
12 & 1,48 \\
13 & 1,56 \\
14 & 1,57 \\
15 & 1,58 \\
\hline
\end{tabular}

\subsection{Konversi AHP menjadi Triangular Fuzzy Number (TFN)}

Triangular Fuzzy Number (TFN) adalah teori himpunan Fuzzy yang membantu dalam pengukuran terkait dengan penilaian subjektif manusia berdasarkan skala linguistik (Elveny dan Rahmadsyah, 2014). Bilangan TFN disimbolkan dengan $\mathrm{M}=(l, m, u)$, dimana $l$ merupakan nilai terendah, $m$ merupakan nilai tengah dan $u$ 
merupakan nilai tertinggi (Beşikçi et al., 2016). Fungsi keanggotaan bilangan fuzzy dalam AHP ditampilkan pada Tabel 3.

Tabel 3 Fungsi keanggotaan bilangan fuzzy

\begin{tabular}{cccl}
\hline Fuzzy scale & TFN Value & Fuzzy Scale Inverse & \multicolumn{1}{c}{ Information } \\
\hline 1 & $(1,1,1)$ & $(1,1,1)$ & Equally important \\
2 & $(1 / 2,1,3 / 2)$ & $(2 / 3,1,2)$ & Middle \\
3 & $(1,3 / 3,2)$ & $(1 / 2,2 / 3,1)$ & A little more important \\
4 & $(3 / 2,2,5 / 2)$ & $(2 / 5,1 / 2,2 / 3)$ & Middle \\
5 & $(2,5 / 2,3)$ & $(1 / 3,2 / 5,1 / 2)$ & More important \\
6 & $(5 / 2,3,7 / 2)$ & $(2 / 7,1 / 3,2 / 5)$ & Middle \\
7 & $(3,7 / 2,4)$ & $(1 / 4,2 / 7,1 / 3)$ & Very important \\
8 & $((7 / 2,4,9 / 2)$ & $(1 / 9,1 / 4,2 / 7)$ & Middle \\
9 & $(4,9 / 2,9 / 2)$ & $(2 / 9,2 / 9,1 / 4)$ & Absolutely more important \\
\hline
\end{tabular}

\subsection{Analisis Fuzzy Synthetic Extend (FSE)}

Tahap analisis Fuzzy Synthetic Extend (FSE) bertujuan untuk mengatasi permasalahan yang terkadang muncul dalam pengambilan keputusan terkait kriteria tangible dan intangible dengan ketidakpastian penilaian. Persamaan (4) adalah rumus yang digunakan untuk menentukan nilai Si (Fuzzy Synthetic Extend). Sedangkan persamaan yang digunakan dalam menentukan degree of possibility ditunjukkan pada persamaan (5) (Kaganski, Majak dan Karjust, 2018).

$$
\begin{aligned}
& S i=\sum_{j=1} M_{g i}^{i} \times\left[\sum_{i=1} \sum_{j=1} \sum_{g i}^{i}\right]^{-1} \\
& V(M 2>M 1)=\left\{\begin{array}{cc}
1 & m 2 \geq m 1 \\
0 & l 1 \geq u 2 \\
\frac{l 2-u 2}{(m 2-u 2)-(m 1-l 1)} & \text { sebaliknya }
\end{array}\right.
\end{aligned}
$$

\subsection{Normalisasi Bobot}

Dari hasil nilai perhitungan degree of possibility, kemudian dilakukan normalisasi bobot. Normalisasi merupakan proses defuzzifikasi untuk mengubah bilangan vektor menjadi non fuzzy (crisp) sehingga menjadi analog bobot kriteria dan sub kriteria (Shega, Rahmawati dan Yasin, 2012). Rumus yang digunakan untuk menentukan nilai crisp ditunjukkan pada persamaan (6).

$$
\operatorname{CRISP}(d i)=\frac{d^{\prime} j}{\sum_{i=1}^{n} d \prime i}
$$

dimana:

di $\quad=$ nilai crisp untuk kriteria $\mathrm{i}$

$\mathrm{d}$ ' $\mathrm{i}=$ nilai minimum degree of possibility untuk kriteria $\mathrm{i}$ 


\section{HASIL DAN PEMBAHASAN}

Pemilihan jenis lampu yang dilakukan pada penelitian ini diawali dengan menyebarkan kuesioner I. Kuesioner I bertujuan untuk menentukan tingkat kepentingan kriteria dan sub kriteria dalam proses penentuan merk lampu. Pada penelitian ini pihak yang menjadi responden yaitu beberapa orang ahli didalam memberikan penilaian maupun keputusan yang berhubungan dengan proses pemilihan lampu. Responden tersebut terdiri dari:

1) dua orang staf Sistem Informasi Manajemen dan Akuntansi Barang Milik Negara (SIMAK BMN) bagian listrik selaku pihak yang bertanggung jawab mengenai kelistrikan yang ada di Perpustakaan;

2) satu orang staf bagian rumah tangga selaku pihak yang bertanggung jawab terhadap adminstrasi yang ada di perpustakaan dan

3) satu orang staf Unit Layanan Pengadaan selaku pihak yang bertanggung jawab terhadap pengadaan barang di Perpustakaan.

Langkah selanjutnya adalah membuat hirarki permasalahan dari kriteria tersebut. Hirarki yang disusun terdiri dari empat level, yaitu level pertama merupakan tujuan, level kedua merupakan kriteria, level ketiga merupakan sub kriteria dan level keempat merupakan alternatif. Hirarki permasalahan pemilihan alternatif lampu dapat dilihat pada Gambar 1.

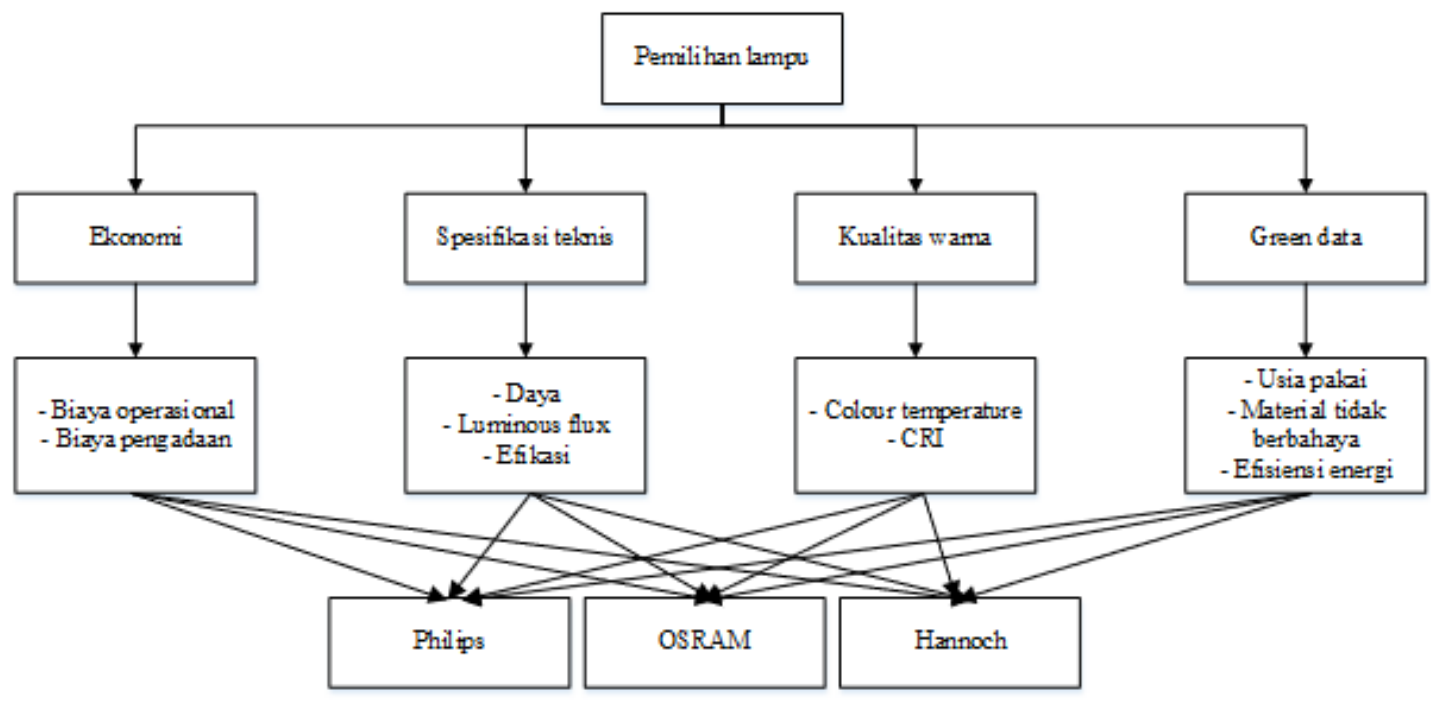

Gambar 1 Struktur hirarki penentuan bobot kriteria pemilihan lampu

Setelah menentukan struktur hirarki langkah berikutnya adalah menyebarkan kuesioner II. Kuesioner II disebarkan kepada responden yang sama pada kuesioner I. Setelah hasil kuesioner diperoleh, langkah berikutnya yaitu membuat matriks perbandingan berpasangan yang hasilnya ditampilkan pada Tabel 4.

Setelah menyusun matriks perbandingan berpasangan langkah selanjutnya adalah melakukan agregasi penilaian responden menggunakan metode rataan geometrik. Metode rataan geometrik dipilih karena penilaian yang digunakan bersifat rasio. Rataan geometrik agregasi penilaian responden kriteria utama dapat dilihat pada Tabel 5. Contoh perhitungan rataan geometrik dengan menggunakan metode agregasi penilaian responden adalah sebagai berikut: 


$$
\begin{aligned}
& R G=\left(x_{1} \cdot x_{2} \cdot x_{3} \ldots x_{n}\right)^{1 / n} \\
& R G C_{1} C_{1}=\left(l c_{11} \cdot l c_{12} \cdot l c_{13}\right)^{1 / 4} \\
& R G C_{1} C_{1}=(1.1 .1 .1)^{1 / 4} \\
& R G C_{1} C_{1}=1
\end{aligned}
$$

Langkah berikutnya adalah melakukan uji konsistensi. Jika nilai CR $<0,1$ maka harus dilakukan perbaikan nilai-nilai yang ada di matriks sebelumnya hingga mencapai nilai CR < 0,1 (Anshori, 2012). Uji konsistensi dapat dilihat pada Tabel 6.

Tabel 4 Matriks perbandingan berpasangan kriteria utama

\begin{tabular}{cccccc}
\hline Kriteria & Responden & $\mathrm{C}_{1}$ & $\mathrm{C}_{2}$ & $\mathrm{C}_{3}$ & $\mathrm{C}_{4}$ \\
\hline $\mathrm{C}_{1}$ & 1 & 1 & $1 / 5$ & $1 / 5$ & $1 / 7$ \\
& 2 & 1 & 1 & $1 / 5$ & 1 \\
& 3 & 1 & 1 & 3 & 1 \\
& 4 & 1 & 1 & 5 & 3 \\
$\mathrm{C}_{2}$ & 1 & 5 & 1 & 5 & 1 \\
& 2 & 1 & 1 & 1 & $1 / 5$ \\
& 3 & 1 & 1 & 3 & 1 \\
& 4 & 1 & 1 & 7 & 3 \\
$\mathrm{C}_{3}$ & 1 & 5 & $1 / 5$ & 1 & $1 / 5$ \\
& 2 & 5 & 1 & 1 & 1 \\
& 3 & $1 / 3$ & $1 / 3$ & 1 & $/ 3$ \\
& 4 & $1 / 5$ & $1 / 7$ & 1 & $1 / 3$ \\
$\mathrm{C}_{4}$ & 1 & 7 & 1 & 5 & 1 \\
& 2 & 1 & 5 & 1 & 1 \\
& 3 & 1 & 1 & 3 & 1 \\
& 4 & $1 / 3$ & $1 / 3$ & 3 & 1 \\
\hline
\end{tabular}

Tabel 5 Rataan geometrik agregasi penilaian responden kriteria utama

\begin{tabular}{lcccc} 
Kriteria & $\mathrm{C}_{1}$ & $\mathrm{C}_{2}$ & $\mathrm{C}_{3}$ & $\mathrm{C}_{4}$ \\
\hline $\mathrm{C}_{1}$ & 1,00 & 0,67 & 0,88 & 0,81 \\
$\mathrm{C}_{2}$ & 1,50 & 1,00 & 3,20 & 0,88 \\
$\mathrm{C}_{3}$ & 1,14 & 0,31 & 1,00 & 0,39 \\
$\mathrm{C}_{4}$ & 1,24 & 1,14 & 2,59 & 1,00 \\
Jumlah & 4,87 & 3,12 & 7,67 & 3,08 \\
\hline
\end{tabular}


Tabel 6 Uji konsistensi kriteria utama dengan sub kriteria

\begin{tabular}{ccccccc}
\hline Kriteria & Sub kriteria & $\lambda$ maks & CI & RI & CR & Keterangan \\
\hline $\mathrm{C}_{1}$ & $\mathrm{C}_{11}$ & 1,00 & $-1,00$ & 0,00 & 0,00 & Konsisten \\
& $\mathrm{C}_{12}$ & & & & & \\
$\mathrm{C}_{2}$ & $\mathrm{C}_{21}$ & 1,00 & $-1,00$ & 0,90 & $-1,11$ & Konsisten \\
& $\mathrm{C}_{22}$ & & & & & \\
& $\mathrm{C}_{23}$ & & & & & \\
$\mathrm{C}_{3}$ & $\mathrm{C}_{31}$ & 1,00 & $-1,00$ & 0,90 & $-1,11$ & Konsisten \\
& $\mathrm{C}_{32}$ & & & & & \\
$\mathrm{C}_{4}$ & $\mathrm{C}_{41}$ & 1,00 & $-1,00$ & 0,90 & $-1,11$ & Konsisten \\
& $\mathrm{C}_{42}$ & & & & & \\
& $\mathrm{C}_{43}$ & & & & & \\
\hline
\end{tabular}

Perhitungan CR untuk kriteria utama adalah sebagai berikut:

1) $\lambda$ maks $=\frac{\sum \text { bobot prioritas }}{n}$

$\lambda$ maks $=\frac{1,06+0,98+0,99+1,01}{4}$

$\lambda$ maks $=1$

2) $C I=\frac{\lambda \text { maks }-\mathrm{n}}{n-1}$

$C I=\frac{1,00-4}{4-1}$

$C I=-1$

3) $C R=\frac{C I}{R I} ;($ Nilai RI dilihat dari Tabel 2)

$C R=\frac{-1}{0,9}$

$C R=-1,1112$ (konsisten)

Hasil pengujian Consistency Ratio untuk kriteria utama adalah -1,1108 Nilai tersebut kurang dari 0,1 sehingga dapat dinyatakan bahwa hasil perhitungan tersebut konsisten.

Langkah berikutnya yaitu melakukan konversi skala linguistik AHP menjadi Triangular Fuzzy Number. Pada Tabel 7 dapat dilihat hasil konversi AHP menjadi TFN untuk kriteria utama dalam bentuk matriks perbandingan berpasangan.

Tabel 7 Konversi TFN kriteria utama

\begin{tabular}{ccccccccccccc}
\hline \multirow{2}{*}{ Kriteria } & \multicolumn{1}{c}{$\mathrm{C}_{1}$} & \multicolumn{1}{c}{$\mathrm{C}_{2}$} & \multicolumn{1}{c}{$\mathrm{C}_{3}$} & \multicolumn{3}{c}{$\mathrm{C}_{4}$} \\
\cline { 2 - 13 } & $l$ & $m$ & $u$ & $l$ & $m$ & $u$ & $l$ & $m$ & $u$ & $l$ & $m$ & $u$ \\
\hline $\mathrm{C}_{1}$ & 1 & 1 & 1 & $2 / 3$ & 1 & 2 & 1 & 1 & 3 & 1 & 1 & 3 \\
$\mathrm{C}_{2}$ & $1 / 2$ & 1 & $11 / 2$ & 1 & 1 & 3 & 1 & $11 / 2$ & 2 & 1 & 1 & 3 \\
$\mathrm{C}_{3}$ & 1 & 1 & 1 & $1 / 2$ & $2 / 3$ & 1 & 1 & 1 & 1 & $1 / 2$ & $2 / 3$ & 1 \\
$\mathrm{C}_{4}$ & 1 & 1 & 1 & 1 & 1 & 3 & 1 & $11 / 2$ & 2 & 1 & 1 & 1 \\
\hline
\end{tabular}

Tahap berikutnya adalah melakukan analisis Fuzzy Synthetic Extend (FSE) yang bertujuan untuk mengatasi permasalahan yang terkadang muncul dalam 
pengambilan keputusan terkait kriteria tangible dan intangible dengan ketidakpastian penilaian. Tahap ini dapat memasukkan ketidakpastian dalam penentuan kriteria dan membandingkan setiap pasangan fungsi keanggotaan yang dibangun untuk tiap kriteria. Tabel 8 memperlihatkan nilai FSE untuk kriteria utama.

Tabel 8 FSE kriteria utama

\begin{tabular}{cccc}
\hline \multirow{2}{*}{ Kriteria } & \multicolumn{3}{l}{$\mathrm{S}_{\mathrm{i}}$} \\
\cline { 2 - 4 } & $l$ & $m$ & $u$ \\
\hline $\mathrm{C}_{1}$ & 0,12 & 0,24 & 0,64 \\
$\mathrm{C}_{2}$ & 0,12 & 0,28 & 0,67 \\
$\mathrm{C}_{3}$ & 0,10 & 0,20 & 0,28 \\
$\mathrm{C}_{4}$ & 0,14 & 0,28 & 0,49 \\
Total & 0,48 & 1,00 & 2,08 \\
\hline
\end{tabular}

Contoh perhitungan pada $\mathrm{Si}$

$$
\begin{aligned}
& S i=\sum_{j=1} M_{g i}^{i} \\
& S i=(3,67,4,9)\left(\frac{1}{29,50}, \frac{1}{16,33}, \frac{1}{14,17}\right) \\
& S i=0,12,0,24,0,64
\end{aligned}
$$

Dari hasil pendekatan fuzzy yang kemudian dibobotkan, didapatkan nilai keanggotaan yang disebut dengan degree of possiblity. Degree of possibility kriteria utama dapat dilihat pada Tabel 9.

Tabel 9 Degree Of Possibility kriteria utama

\begin{tabular}{cccccc} 
Kriteria & $\mathrm{C}_{1}$ & $\mathrm{C}_{2}$ & $\mathrm{C}_{3}$ & $\mathrm{C}_{4}$ & Min \\
\hline $\mathrm{C}_{1}$ & 1,00 & 0,94 & 1,00 & 0,94 & 0,94 \\
$\mathrm{C}_{2}$ & 1,00 & 1,00 & 1,00 & 1,00 & 1,00 \\
$\mathrm{C}_{3}$ & 0,79 & 0,70 & 1,00 & 0,67 & 0,67 \\
$\mathrm{C}_{4}$ & 1,00 & 1,00 & 1,00 & 1,00 & 1,00 \\
Total & & & & & 3,61 \\
\hline
\end{tabular}

Contoh perhitungan Degree of Possibility kriteria utama.

$V(M 2>M 1)=\sup \left[\min \left(\mu_{M 1}(x),\left(\mu_{M 1}(y)\right)\right]\right.$, dimana $x$ dan $y$ merupakan nilainilai pada sumbu dan fungsi keanggotaan tiap kriteria. Persamaan diatas dapat didefinisikan sebagai berikut:

$V(M 2>M 1)=\left\{\begin{array}{cc}1 & , m 2 \geq m 1 \\ 0 & l 1 \geq u 2 \\ \frac{l 2-u 2}{(m 2-u 2)-(m 1-l 1)} & \text { sebaliknya }\end{array}\right.$

$\mathrm{Mc} 2 \geq \mathrm{Mc} 1=\mathrm{mc} 2 \geq \mathrm{mc} 1=1$

Tahap akhir dalam Fuzzy AHP yang membedakan dengan metode AHP adalah tahap normalisasi bobot. Hasil perhitungan normalisasi bobot untuk kriteria utama dapat dilihat pada Tabel 10. 
Tabel 10 Normalisasi bobot kriteria utama

\begin{tabular}{ccccc}
\hline \multicolumn{3}{c}{ Vektor bobot } & Normalisasi & Bobot Crisp \\
\hline $\mathrm{d}^{\prime} \mathrm{C}_{1}$ & $\min$ & 0,94 & $\mathrm{C}_{1}$ & 0,26 \\
$\mathrm{~d}^{\prime} \mathrm{C}_{2}$ & $\min$ & 1,00 & $\mathrm{C}_{2}$ & 0,28 \\
$\mathrm{~d}^{\prime} \mathrm{C}_{3}$ & $\min$ & 0,67 & $\mathrm{C}_{3}$ & 0,19 \\
$\mathrm{~d}^{\prime} \mathrm{C}_{4}$ & $\min$ & 1,00 & $\mathrm{C}_{4}$ & 0,28 \\
Jumlah & 3,61 & & \\
\hline
\end{tabular}

Setelah dilakukan pembobotan, langkah berikutnya yaitu dilakukan pemilihan alternatif berdasarkan hasil pembobotan yang telah diperoleh. Rekapitulasi hasil pembobotan untuk semua kriteria dan sub kriteria terdapat pada Tabel 11.

Contoh perhitungan bobot sub kriteria adalah sebagai berikut:

1) Bobot sub kriteria biaya operasional =

Bobot kriteria ekonomi $x$ Bobot sub kriteria biaya operasional

Bobot sub kriteria biaya operasional $=0,26 \times 1$

Bobot sub kriteria biaya operasional $=0,26$

2) Berikut adalah contoh perhitungan bobot alternatif alternatif 1 terhadap kriteria $C_{1}$ dan sub kriteria $\mathrm{C}_{11}$

Bobot alternatif $1=$ Bobot $C_{1} \times$ Bobot alternatif 1

Bobot alternatif $1=0,26 \times 0,45$

Bobot alternatif $1=0,12$

Tabel 11 Rekap hasil pembobotan untuk semua kriteria

\begin{tabular}{|c|c|c|c|c|c|c|c|c|}
\hline $\begin{array}{l}\text { Level } 0 \\
\text { (tujuan) }\end{array}$ & \multicolumn{2}{|c|}{ Level 1 (Kriteria) } & \multicolumn{2}{|c|}{$\begin{array}{c}\text { Level } 2 \\
\text { (Sub kriteria) }\end{array}$} & \multirow{3}{*}{$\begin{array}{c}\begin{array}{c}\text { Bobot sub } \\
\text { kriteria }\end{array} \\
0,26\end{array}$} & \multicolumn{2}{|c|}{ Alternatif } & \multirow{2}{*}{$\frac{\text { Bobot }}{0,12}$} \\
\hline \multirow{20}{*}{$\begin{array}{l}\text { Pemilihan } \\
\text { lampu }\end{array}$} & \multirow{6}{*}{$\begin{array}{c}\text { Ekonomi } \\
\left(\mathrm{C}_{1}\right)\end{array}$} & \multirow[t]{6}{*}{0,261} & \multirow{3}{*}{$\begin{array}{l}\text { Biaya } \\
\text { operasional } \\
\left(\mathrm{C}_{11}\right)\end{array}$} & \multirow[t]{3}{*}{1,00} & & Philips & 0,45 & \\
\hline & & & & & & OSRAM & 0,45 & 0,12 \\
\hline & & & & & & Hannoch & 0,09 & 0,02 \\
\hline & & & \multirow{3}{*}{$\begin{array}{l}\text { Biaya } \\
\text { pengadaan } \\
\left(\mathrm{C}_{12}\right)\end{array}$} & \multirow[t]{3}{*}{0,00} & \multirow[t]{3}{*}{0,00} & Philips & 0,73 & 0,00 \\
\hline & & & & & & OSRAM & 0,27 & 0,00 \\
\hline & & & & & & Hannoch & 0,00 & 0,00 \\
\hline & \multirow{9}{*}{$\begin{array}{l}\text { Spesifikasi } \\
\text { teknis }\left(C_{2}\right)\end{array}$} & \multirow[t]{9}{*}{0,277} & \multirow[t]{3}{*}{ Daya $\left(\mathrm{C}_{21}\right)$} & \multirow[t]{3}{*}{0,15} & \multirow[t]{3}{*}{0,04} & Philips & 0,38 & 0,02 \\
\hline & & & & & & OSRAM & 0,38 & 0,02 \\
\hline & & & & & & Hannoch & 0,24 & 0,01 \\
\hline & & & \multirow{3}{*}{$\begin{array}{l}\text { Luminous } \\
\text { flux }\left(\mathrm{C}_{22}\right)\end{array}$} & \multirow[t]{3}{*}{0,27} & \multirow[t]{3}{*}{0,07} & Philips & 0,46 & 0,03 \\
\hline & & & & & & OSRAM & 0,46 & 0,03 \\
\hline & & & & & & Hannoch & 0,09 & 0,01 \\
\hline & & & \multirow[t]{3}{*}{ Efikasi $\left(\mathrm{C}_{23}\right)$} & \multirow[t]{3}{*}{0,58} & \multirow[t]{3}{*}{0,16} & Philips & 0,44 & 0,07 \\
\hline & & & & & & OSRAM & 0,39 & 0,06 \\
\hline & & & & & & Hannoch & 0,17 & 0,03 \\
\hline & \multirow{5}{*}{$\begin{array}{c}\text { Kualitas } \\
\text { warna }\left(C_{3}\right)\end{array}$} & \multirow[t]{5}{*}{0,186} & \multirow{3}{*}{$\begin{array}{l}\text { Colour } \\
\text { temperature } \\
\left(\mathrm{C}_{31}\right)\end{array}$} & \multirow[t]{3}{*}{0,36} & \multirow[t]{3}{*}{0,07} & Philips & 0,57 & 0,04 \\
\hline & & & & & & OSRAM & 0,21 & 0,01 \\
\hline & & & & & & Hannoch & 0,22 & 0,01 \\
\hline & & & \multirow[t]{2}{*}{$\mathrm{CRI}\left(\mathrm{C}_{32}\right)$} & \multirow[t]{2}{*}{0,64} & \multirow[t]{2}{*}{0,12} & Philips & 0,37 & 0,04 \\
\hline & & & & & & OSRAM & 0,34 & 0,04 \\
\hline
\end{tabular}




\begin{tabular}{|c|c|c|c|c|c|c|c|c|}
\hline \multirow[t]{2}{*}{$\begin{array}{l}\text { Level } 0 \\
\text { (tujuan) }\end{array}$} & \multicolumn{2}{|c|}{ Level 1 (Kriteria) } & \multicolumn{2}{|c|}{$\begin{array}{c}\text { Level } 2 \\
\text { (Sub kriteria) }\end{array}$} & $\begin{array}{c}\text { Bobot sub } \\
\text { kriteria }\end{array}$ & \multicolumn{2}{|c|}{ Alternatif } & \multirow{2}{*}{$\begin{array}{l}\text { Bobot } \\
0,03\end{array}$} \\
\hline & \multirow{10}{*}{$\begin{array}{l}\text { Green data } \\
\quad\left(\mathrm{C}_{4}\right)\end{array}$} & \multirow{10}{*}{0,277} & & & \multirow{4}{*}{0,09} & Hannoch & 0,29 & \\
\hline & & & \multirow{3}{*}{$\begin{array}{l}\text { Usia pakai } \\
\left(\mathrm{C}_{41}\right)\end{array}$} & \multirow[t]{3}{*}{0,33} & & Philips & 0,41 & 0,04 \\
\hline & & & & & & OSRAM & 0,33 & 0,03 \\
\hline & & & & & & Hannoch & 0,26 & 0,02 \\
\hline & & & \multirow{3}{*}{$\begin{array}{l}\text { Material tidak } \\
\text { berbahaya } \\
\left(\mathrm{C}_{42}\right)\end{array}$} & \multirow[t]{3}{*}{0,33} & \multirow[t]{3}{*}{0,09} & Philips & 0,38 & 0,03 \\
\hline & & & & & & OSRAM & 0,40 & 0,04 \\
\hline & & & & & & Hannoch & 0,22 & 0,02 \\
\hline & & & \multirow{3}{*}{$\begin{array}{l}\text { Efisiensi } \\
\text { energi }\left(\mathrm{C}_{43}\right)\end{array}$} & \multirow[t]{3}{*}{0,33} & \multirow[t]{3}{*}{0,09} & Philips & 0,41 & 0,04 \\
\hline & & & & & & OSRAM & 0,33 & 0,03 \\
\hline & & & & & & Hannoch & 0,26 & 0,02 \\
\hline
\end{tabular}

Selanjutnya dilakukan perhitungan alternatif terpilih. Pada Tabel 12 disajikan hasil perhitungan alternatif terpilih.

Tabel 12 Hasil perhitungan alternatif terpilih

\begin{tabular}{lcc} 
Alternatif & Bobot & Ranking \\
\hline Philips & $43 \%$ & 1 \\
OSRAM & $38 \%$ & 2 \\
Hannoch & $18 \%$ & 3 \\
Jumlah & $100 \%$ & \\
\hline
\end{tabular}

Berikut adalah contoh perhitungan alternatif Philips.

Alternatif Philips

$$
\begin{aligned}
& =0,12 \times 0,00 \times 0,02 \times 0,03 \times 0,07 \times 0,04 \times 0,04 \times 0,04 \times 0,04 \times 0,03 \\
& \times 0,04
\end{aligned}
$$

Alternatif Philips $=0,43$

\section{KESIMPULAN}

Metode fuzzy AHP yang digunakan dalam penelitian ini mampu memberikan perangkingan dari kriteria-kriteria yang digunakan untuk memilih lampu. Kriteria yang digunakan yaitu ekonomi dengan sub kriteria biaya operasional dan biaya pengadaan, spesifikasi teknis dengan sub kriteria daya, luminous flux dan efikasi, kualitas warna dengan sub kriteria colour temperature dan CRI, Green Data dengan sub kriteria usia pakai, material tidak berbahaya dan efisiensi energi. Berdasarkan hasil perankingan menggunakan metode fuzzy AHP diperoleh hasil bahwa lampu yang terpilih pada prioritas 1 yaitu Philips dengan bobot sebesar $43 \%$, prioritas 2 OSRAM dengan bobot sebesar 38\%, dan prioritas 3 Hannoch dengan bobot sebesar $18 \%$.

\section{DAFTAR PUSTAKA}

Andalia, Y. A., Iftadi, I. dan Jauhari, W. A., 2014, Pengembangan Metode Pengukuran Usabilitas Surel Dengan Fuzzy AHP Menurut Dimensi ISO 9421 Part 11, Performa, 13(1), 69-80. doi: https://doi.org/10.20961/performa.13.1.12716. 
Anshori, Y., 2012, Pendekatan Triangular Fuzzy Number Dalam Metode Analytic Hierarchy Process, Jurnal Ilmiah Foristek, 2(1), 126-135.

Bai, K., Zhu, X., Wang, J., \& Zhang, R., 2018, Some partitioned Maclaurin symmetric mean based on q-rung orthopair fuzzy information for dealing with multiattribute group decision making, Symmetry, 10(9), 383. doi: 10.3390/sym10090383.

Beşikçi, E. B. et al., 2016, An application of fuzzy-AHP to ship operational energy efficiency measures, Ocean Engineering, 121, 392-402. doi: 10.1016/j.oceaneng.2016.05.031.

Ekastini, Kusrini dan Luthfi, E. T., 2018, Penerapan Metode Fuzzy Analytical Hierarchy Process untuk SPK Penyeleksian Naskah Layak Terbit, Creative Information Technology Journal, 4(2), 117-126. doi: 10.24076/citec.2017v4i2.103.

Elveny, M. dan Rahmadsyah, 2014, Analisis Metode Fuzzy Analytic Hierarchy Process (F-AHP) Dalam Menentukan Posisi Jabatan, TECHSI - Jurnal Penelitian Teknik Informatika, 4(1), 111-126.

Fajri, M., Putri, R. R. M. dan Muflikhah, L., 2018, Implementasi Metode Fuzzy Analytic Hierarchy Process (F-AHP) Dalam Penentuan Peminatan di MAN 2 Kota Serang, Jurnal Pengembangan Teknologi Informasi dan Ilmu Komputer (J-PTIIK) Universitas Brawijaya, 2(5), 2109-2117.

Hadikurniawati, W. dan Amin, I. H. Al, 2016, Multi-Attribute Decision Making Dalam Pemilihan Lampu Pada Sistem Pencahayaan Lapangan Badminton," Jurnal Informatika Upgris, 2(2), 75-82. doi: 10.26877/jiu.v2i2.1267.

Kaganski, S., Majak, J. dan Karjust, K., 2018, Fuzzy AHP as a tool for prioritization of key performance indicators, Procedia CIRP. Elsevier B.V., 72, 1227-1232. doi: 10.1016/j.procir.2018.03.097.

Mardani, A., Zavadskas, E. K., Streimikiene, D., Jusoh, A., Nor, K. M., \& Khoshnoudi, M., 2016, Using fuzzy multiple criteria decision making approaches for evaluating energy saving technologies and solutions in five star hotels: A new hierarchical framework, Energy. Elsevier Ltd, 117, 131-148. doi: 10.1016/j.energy.2016.10.076.

Mardhikawarih, D. A., Jauhari, W. A. dan Rosyidi, C. N., 2012, Pemilihan Pemasok Drum Pelumas Industri Menggunakan Fuzzy Analytical Hierarchy Process," Performa, 11(1), 67-74.

Milaningrum, T. H., 2015, Optimalisasi Pencahayaan Alami dalam Efisiensi Energi di Perpustakaan UGM, in Prosiding Seminar Topik Khusus, 1-10.

Nirmala, G. dan Uthra, G., 2019, AHP based on triangular intuitionistic fuzzy number and its application to supplier selection problem, Materials Today: Proceedings. Elsevier Ltd., 16, 987-993. doi: 10.1016/j.matpr.2019.05.186. 
Omar, O., García-Fernández, B., Fernandez-Balbuena, A. A., \& Vázquez-Moliní, D., 2018, Optimization of daylight utilization in energy saving application on the library in faculty of architecture, design and built environment, Beirut Arab University, Alexandria Engineering Journal, 57(4), 3921-3930. doi: 10.1016/j.aej.2018.10.006.

Saaty, T.L., 1994, Fundamental of Decision Making and Priority Theory with the Analytical Hierarchy Process, Pittsburg: RWS Publication.

Saaty, T. L., \& Vargas, L. G., 2012, The seven pillars of the analytic hierarchy process. In Models, methods, concepts \& applications of the analytic hierarchy process, 23-40, Boston, MA: Springer.

Shega, H. N. H., Rahmawati, R. dan Yasin, H., 2012, Penentuan Faktor Prioritas Mahasiswa Dalam Memilih Telepon Seluler Merk Blackberry degan Fuzzy AHP, Jurnal Gaussian, 1(1), 73-82.

Sonalitha, E., Sarosa, M. dan Naba, A., 2015, Pemilihan Pemasok Bahan Mentah pada Restoran Menggunakan Metode Fuzzy Analytical Hierarchy Process, Jurnal EECCIS, 9(1), 49-54.

Zarghami, E., Azemati, H., Fatourehchi, D., \& Karamloo, M., 2018, Customizing well-known sustainability assessment tools for Iranian residential buildings using Fuzzy Analytic Hierarchy Process, Building and Environment, 128, 107128. doi: 10.1016/j.buildenv.2017.11.032. 